\title{
Volatile compounds in meat and meat products
}

\author{
Monika KOSOWSKA ${ }^{1,2 *}$, Małgorzata A. MAJCHER ${ }^{3}$, Teresa FORTUNA ${ }^{1}$
}

\begin{abstract}
Meaty flavor is composed of a few hundreds of volatile compounds, only minor part of which are responsible for the characteristic odor. It is developed as a result of multi-directional reactions proceeding between non-volatile precursors contained in raw meat under the influence of temperature. The volatile compounds are generated upon: Maillard reactions, lipid oxidation, interactions between Maillard reaction products and lipid oxidation products as well as upon thiamine degradation. The developed flavor is determined by many factors associated with: raw material (breed, sex, diet and age of animal, conditions and process of slaughter, duration and conditions of meat storage, type of muscle), additives applied and the course of the technological process. The objective of this review article is to draw attention to the issue of volatile compounds characteristic for meat products and factors that affect their synthesis.
\end{abstract}

Keywords: volatile compounds; meat flavor; precursors; meat products.

Practical Application: Use of volatile compounds in identity testing of meat and meat products.

\section{Introduction}

Meat and meat products constitute an important source of protein in man's diet and their intake is determined by socio-economic factors, ethical issues, religious beliefs and tradition (Font-I-Furnols \& Guerrero, 2014). The quality of these products and their attractiveness to consumers are, in great part, attributable to the palatability being a sum of gustatory and olfactory sensations and sensory perception.

Raw meat is described as salty, metallic and rare (bloody) with slightly sweet aroma (Soncin et al., 2007). It is weakly-flavored, however it constitutes a rich source of compounds being precursors of volatile compounds. Already heat treatment initiates a series of reactions that result in the development of the characteristic flavor of meat. These reactions are multi-directional and include: Maillard reactions, lipid oxidation, interactions between Maillard reaction products and lipid oxidation products as well as thiamine degradation (MacLeod, 1998). Heat treatment of lean meat (beef, pork, poultry and lamb) imparts non-species-specific meaty flavor, whereas warming up meat containing fat, especially phospholipids and to a lesser extent triglycerides, causes the development of a species-specific flavor of meat (Warris, 2000). Thousands of volatile compounds are generated during thermal processing that belong to various chemical classes: hydrocarbons, alcohols, aldehydes, ketones, carboxylic acids, esters, lactones, furans, pyrrans, pyrroles, pyrazines, pyridines, phenols, thiophenes, thiazoles, thiazolines, oxazoles, and other nitrogen or sulfuric compounds. The species-specific flavor of meat is determined by mixtures of volatile compounds which in the case of heat-treated products may include even a few hundreds of compounds, e.g. ca. 880 of volatile compounds were identified in cooked beef (Mottram, 1994). The contribution of individual volatile compounds in developing the characteristic flavor varies. Only a small part of this vast number of volatile compounds occurring in food products contributes to flavor development. Hence, it is extremely important to separate aroma-active compounds from the other odorless food constituents (Grosch, 1993). It is estimated that only $3 \%$ out of ca. 10,000 identified volatile compounds are capable of imparting odors to food products (Hofmann et al., 2014).

The odor of a food product is characterized by means of the Odor Activity Value (OAV), which is calculated as the ratio between the concentration of a volatile substance and its sensory threshold (Table 1).

The flavor of a meat species is a mixture of volatile compounds representing various flavor notes. In cooked meet, apart from typically meaty flavor notes, like:2-metyl-3-furantiol or bis-(2-methyl-3-furan) disulfide, there also occur compounds characterized by green, mushroom-like, sweet, and earth-like odors, however taken all together they reflect a typical character of a food product (Cerny, 2012).

The objective of this review article is to present volatile compounds and factors which affect their changes in meat and meat products.

\section{Precursors of volatile compounds in meat}

Raw meat is characterized by a very weak odor, however it constitutes a matrix rich in non-volatile precursors of volatile compounds responsible for the development of meat products flavor (Table 2). It contains amino acids, peptides, saccharides, 
Table 1. Odor detection thresholds, flavor notes and odor activity values of selected volatile compounds.

\begin{tabular}{|c|c|c|c|c|}
\hline Volatile compounds & $\begin{array}{l}\text { Odor detection threshold OT } \\
{[\mu \mathrm{g} / \mathrm{L} \text { water }]}\end{array}$ & Odor note & $\begin{array}{c}\text { Odor activity value } \\
\text { OVA }\end{array}$ & Source \\
\hline acetic acid & $135^{\mathrm{a}}$ & pungent, sour & 8830 & \multirow{5}{*}{$\begin{array}{c}\text { Hungarian-Type Salami } \\
\text { (Söllner \& Schieberle, 2009) }\end{array}$} \\
\hline acetaldehyde & $0.24^{\mathrm{a}}$ & fruity & 1610 & \\
\hline methional & 0.2 & cooked potato-like & 740 & \\
\hline phenylacetaldehyde & 24 & honey-like & 330 & \\
\hline 2-methoxyphenol & 17 & smoky, sweet & 213 & \\
\hline 3-mercapto-2-methylpentan-1-ol & 0.0016 & gravy-like & 4800 & \multirow{4}{*}{$\begin{array}{c}\text { Beef vegetable gravy } \\
\text { (Christlbauer \& Schieberle } \\
\text { 2011) }\end{array}$} \\
\hline 12-methyltridecanal & 0.1 & tallow-like & 3600 & \\
\hline (E,E)-2,4-decadienal & 0.2 & fatty, deep fried & 2600 & \\
\hline (E,Z)-2,6-nonadienal & 0.02 & cucumber-like & 285 & \\
\hline
\end{tabular}

${ }^{\mathrm{a} O T}$ in $\mu \mathrm{g} / \mathrm{L}$ oil.

Table 2. Precursors of selected volatile compounds in meat products (Huang \& Ho, 2001; Balagiannis et al., 2009).

\begin{tabular}{cc}
\hline Precursors & Volatile compounds formed \\
\hline Cysteine, monosaccharides & 2-acetyl-2-thiazoline \\
Proline, reducing sugars & 2-acetyl-1-pyrroline \\
Methionine, monosaccharides & methional \\
Cysteine, ribose & 2-furanmethanothiol \\
Leucine, isoleucine, glucose & 3-methylbutanal, 2-methylbutanal \\
Thiamine, cysteine/ribose & 2-methyl-3-furanthiol, bis(2-methyl-3-furyl)disulfide \\
Fatty acids & (E)-2-nonenal, (E,E)-2,4-decadienal, 1-okten-3-on \\
\hline
\end{tabular}

inorganic salts and inorganic acids (MacLeod, 1998). The key role is, however, ascribed to amino acids and peptides as well as reducing sugars. They are formed during post-slaughter transformations occurring in meat upon the activity of enzymes, including degradation of proteins firstly to peptides and then to amino acids (Meinert et al., 2007) and degradation of glycogen to glucose (Meinert et al., 2009). An important fraction in volatiles synthesis is the fatty tissue which undergoes transformations that result in the formation of a multiple reactive substances, like: acids, alcohols, aldehydes or ketones (Mottram, 1998).

Peptides and oligopeptides formed during meat ripening process enhance the flavor of meat. A special role is ascribed in this process to small peptides (3-10 kD) (Claeys et al., 2004), the so-called Maillard's peptides - 1-5 kD (Ogasawara et al., 2006) and oligopeptides rich in glutamic acid (Henriksen \& Stahnke, 1997). Free amino acids, particularly the sulfuric ones like cysteine and methionine, are the basic substrates in Maillard reactions and Strecker's degradation reaction (Majcher \& Jeleń, 2007). Interactions of sugars with sulfuric amino acids result in the formation of many key volatile compounds with characteristics meaty flavor notes (Elmore et al., 2002). In turn, interactions of sulfur-free amino acids with sugars lead to the formation of nitrogen compounds like, e.g. pyrazines (Ames et al., 1997). The synthesis of pyrazines was found to be enhanced by the addition of glycine (Parker et al., 2009). As a result of Strecker reaction, phenylalanine is degraded to phenylacetaldehyde characterized by a slightly sweet taste and honey-like odor, whereas methionine is degraded to methional with a typical odor of cooked potatoes (Granvogl et al., 2012).

Processes of glycogenolysis and glycolysis occurring in meat result in the synthesis of glucose and glucose-6-phosphate, whereas degradation of ATP results in the formation of ribose and ribose-5-phosphate. Sugars form many volatile compounds in reactions with amino acids, e.g. glucose forms pyrazines with lysine (Ames et al., 2001), and ribose forms many key sulfur compounds with cysteine, like e.g.: 2-furanmethanethiol, 3-mercapto-2-pentanone, 2-methyl-3-furanthiol, 3-mercapto-2butanone, bis(2-methyl-3-furyl) disulfide, 2-acetyl-2-thiazoline, 1-mercapto-2-propanone and 3-methyl-3-thiophenethiol (Hofmann \& Schieberle, 1995; Cerny \& Davidek, 2003).

Fats and fatty acids play a significant role in imparting a specific flavor to particular meat species. The main fraction of lipids responsible for the formation of specific volatiles includes phospholipids (Soncin et al., 2007), and to a lesser extent triacylglycerols (Meinert et al., 2007). This specificity is due to differences in fatty acid profiles in various species of animals. The fatty acids contained in phospholipids are more unsaturated compared to the acids occurring in triacylglycerols. Phospholipids contain relatively high amounts of linolenic and arachidic acids, that are subject to auto-oxidation processes which result in the formation of: 2,4-decadienal, 2-nonenal, 1-octen-3-one, 2,4-nonadienal (Perez-Alvarez et al., 2010). The most intensive compound being a product of arachidic acid oxidation is trans-4,5-epoxy-(E)-2-decenal, which is followed by 1-octen-3-one, 2,4-decadienal, 2,4,7-tridecatrienal and hexanal (Blank et al., 2001). The oxidized lipids enter into reactions with Maillard reaction products, which results in the synthesis of many important compounds like pyrazines, thiazoles and thiols.

Thiamine is an important vitamin that naturally occurs in meat. In pork its content ranges from 0.8 to $1.1 \mathrm{mg} / 100 \mathrm{~g}$ (Gerber et al., 2009). Thermal degradation of thiamine results in the formation of transient and final volatile compounds 
which affect odor development in meat products, like thiazoles, thiophenes and furans. Volatiles are formed that are characterized by the following flavor notes: meaty (2-methyl-3-furanthiol, bis (2-methyl-3-furyl) disulfide, 3-thiophenethiol, 2-firmyl-5methylthiophene, 2-methyl-3-(methyldithio) furan), earth-like (4,5-dimetylthiazole), burnt (2-acethylthiophene) and green (2-methyl-4,5-dihydro-3(2H)-thiophenone) (Ba et al., 2012).

\section{Factors affecting changes in volatile compounds}

The composition of volatile compounds in the finished product is influenced by a variety of factors: breed, sex, diet and age of an animal; conditions and process of slaughter; duration and conditions of meat storage; type of muscle; preparation of meat and type of additives applied as well as condition of heat treatment (cooking, roasting, smoking).

Investigations have demonstrated that the palatability of meat differs significantly as affected by the breed it originates from. For instance, beef originating from Friesian cattle is characterized by stronger greasy flavor notes and aftertaste compared to meat of Pirenaica breed cattle, which is due to differences in volatiles composition. Meat obtained from bulls is characterized by a stronger liver-like and rare (bloody) odor compared to the meat of heifers. It is linked with the content of such volatile compounds as: hydrocarbons, aldehydes, alcohols and ketones (Gorraiz et al., 2002). Beef produced from cattle of Wagyu breed is more flavored than the meat obtained from dairy breeds. In addition, it contains more volatiles and higher concentrations of volatile acids, lactones and aldehydes compared to the meat of dairy breeds characterized by the high content of aldehydes and alcohols (Sato et al., 1995). Animals' diet has a great impact on the palatability of the produced meat and, consequently, on the volatile compounds formed (Wood et al., 2008). Cattle feeding with cereal grain increases carcass weight and intramuscular fat content compared to the feeding with green forage. Beef originating from animals administered green forage is characterized by a higher content of linolenic acid and by lower contents of oleic and linoleic acids than the beef produced from animals administered feed concentrates, which eventually affects also the volatiles formed (Elmore et al., 2004). Generally, meat obtained from the organic production system has taste and aroma that are more desirable by consumers (Horsted et al., 2012). In turn, meat of sheep grazing on pastures is rich in terpenes and diterpenoids, whereas that of sheep administered feed mixtures is characterized by a high concentration of $\gamma$-lactones. Sivadier et al. (2010) suggests that 2,3-octanedione may be a biomarker confirming that lamb meat originates from animals feeding on pastures. A special effect in poultry meat flavor development is ascribed to the linolenic acid, however a diet rich in flaxseed and rapeseed oils and in fish meat may have a negative impact by imparting extrinsic odor and taste (Kostecka \& Łobacz, 2009). In contrast, positive changes in aroma compounds are observed upon animal diet supplementation with tocopherols (Milczarek et al., 2013) and herbs (Maślanko \& Pisarski, 2009). A diet rich in tocopherols and selenium prevents the formation of sulfur compounds that are undesirable in raw meat (Wojtasik-Kalinowska et al., 2016).
Various muscles dissected from the same animal differ in their palatability. Generally, the muscles with a higher kinetic activity display stronger flavor compared to the less active muscles (Castellini et al., 2008).

The post-slaughter ripening of meat affects its tenderness as well as develops its flavor profile. The compounds released post-mortem like: sugars, amino acids, peptides, organic acids and products of adenine nucleotide degradation, affect the development of the final flavor of meat (Liu et al., 2012). Non-ripened beef has a weak, bland aroma, whereas the ripening process increases and intensifies its flavor. The ripening for up to 14 days increases the greasy taste and the positively evaluated notes like: beef-like, broth-like, sweet, caramel, but also the negatively perceived ones likes: cardboard-like, bitter and sour (Bruce et al., 2005). Aroma-active volatiles are then form mainly as a result of lipid oxidation processes, e.g.: nonanal, 2,3-octanedione, pentanal, 3-hydroxy-2-butanone, 2-pentyl furan, 1-octen-3-ol, butanoic acid, pentanal and hexanoic acid (Stetzer et al., 2008).

They key role in meat products flavor development is ascribed to temperature, duration and type of the heat treatment applied. A number of reactions proceed during heat treatment that result in the formation of hundreds of volatiles responsible for the species-specific meat flavor. Meat is exposed to various thermal processes, including: roasting, frying, grilling and cooking. High temperatures induce the formation of vast amounts of heterocyclic compounds. Hence, many pyrazine, pyridines, pyrroles and thiazoles were identified in roasted and fried chicken meat, but not in chicken broth (Shi \& Ho, 1994). The roasting of meat enhances oxidation process compared to other methods of heat treatment due to prolonged meat exposure to high temperatures (Domínguez et al., 2014). A strong correlation exists between heating temperature, concentration of free amino acids, carnosine, IMP, pyrazines and hexanol and the intensity of taste of roasted, burnt and cooked beef (Lorenzen et al., 2005).

\section{Formation of volatile compounds in meat and meat products}

The development of a characteristic flavor of cooked meat is attributable to volatiles generated during heating as a result of the following processes: Maillard reaction, lipid oxidation, interactions between Maillard reaction products and lipid oxidation products, and thermal degradation of thiamine (Figure 1) (MacLeod, 1998). The Maillard reaction consists in the interactions of reducing sugars (e.g. ribose, glucose) and free amino compounds (e.g. amino acids, peptides) under the influence of temperature and results in the formation of the so-called Maillard reaction products. The reaction is described as a three-stage one. At the first stage, the carbonyl group of a reducing sugar is condensed with the amine group. This reaction results in the formation of $\mathrm{N}$-substituted glycosylamine, also referred to as an Amadori product. At the successive stage, fragmentation of sugars proceeds and amine groups are released. The final stage of Maillard reaction involves the processes of: dehydration, fragmentation, cyclization and polymerization, which lead to the formation of brown pigments and flavor compounds (Van Boekel, 2006). Among the phenomena occurring during Maillard reaction, worthy of special attention is Strecker degradation, when amino 


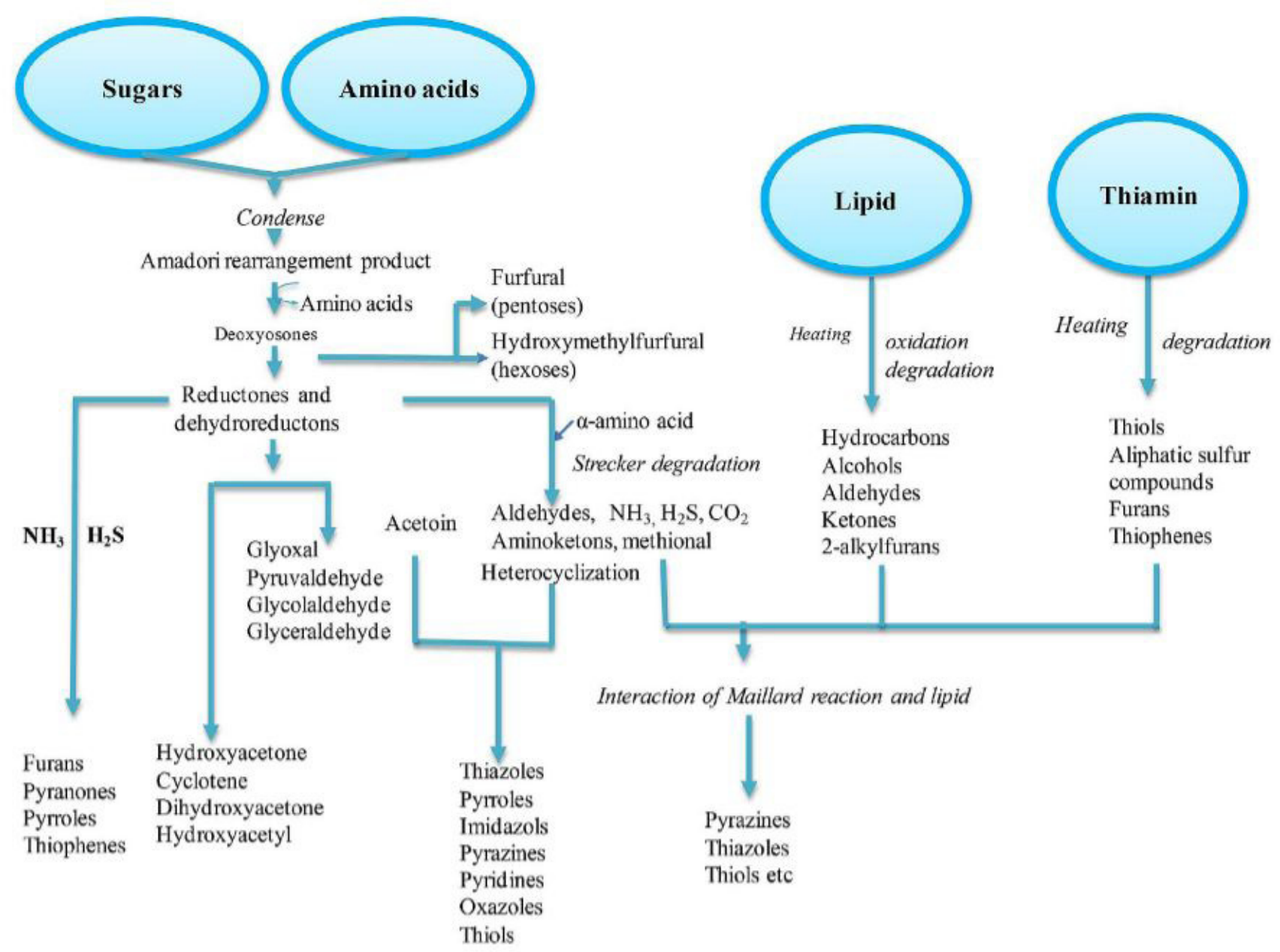

Figure 1. Schematic illustration of volatile compounds generated by Maillard reaction between sugars and amino acids; heat degradation of lipid and thiamine (Dashdorj et al., 2015).

acids are degraded in the presence of dicarbonyl compounds being products of the Maillard reaction. These transformations result in the synthesis of aldehydes and aminoketones, but also $\mathrm{NH}_{3}$ and $\mathrm{H}_{2} \mathrm{~S}$ that are formed from sulfur-containing amino acids, like e.g. cysteine. The Strecker degradation products are subject to successive interactions with other components, which leads to the formation of aroma compounds (Ba et al., 2012).

Hundreds of volatile compounds determined in cooked meat include products of lipid and fatty acid oxidation, e.g. aliphatic hydrocarbons, aldehydes, ketones, alcohols, carboxylic acids, and esters. Sensory detection thresholds of lipid oxidation products are significantly higher compared to these of the heterocyclic compounds containing nitrogen or sulfur that are formed during Maillard reaction. Many of them are insignificant to flavor development, however the saturated and unsaturated aldehydes, which contain 6 to 10 atoms of carbon, play a significant role in this process (Mottram, 1998).

Interactions between Maillard reaction products and lipids have been extensively studied in model systems (Elmore et al., 2002; Pan et al., 2011). These investigations included analyses of the course of cysteine and ribose interactions with various types of fat. They demonstrated that the addition of fat affected the volatile compounds formed. Degradation products of polyunsaturated fatty acids, n-3 acids in particular, with a shorter chain length and a lower sensory detection threshold occur in higher concentrations and exhibit higher reactivity. They suppress the formation of sulfur compounds like e.g. thiophenes and furans. Due to their high reactivity, they increase the levels of fatty acids degradation products, of n- 6 and n-9 families, which in turn affects the final flavor of heat-treated meat products (Elmore et al., 2002). During the heating of cysteine, ribose and lecithin, changes were observed in the volatile compounds formed, i.e. alcohols and alkylfurans were generated instead of aldehydes (Farmer \& Mottram, 1992). It was also confirmed in a study conducted by Pan et al. (2011), which demonstrated an inhibiting effect of fat addition in a reaction mixture composed of cysteine, xylose and pork fat on many sulfur compounds, in particular on: 2-methyl-3-furanthiol, 2-furanmethanethiol, 2-methylthiophene and 3-methylthiophene. One of the intermediate compounds, i.e. furfural, was synthesized in a lower concentration, whereas alcohols, alkyl furans and aliphatic acids were formed instead of aldehydes. Investigations have also been carried out to examine the effect of selected oils on the formation of volatile compounds. The oils were found to exert a direct effect on the profile of the generated pyrazines (Negroni et al., 2001). 
Investigations have also addressed the effect of thiamine addition on the formation of key volatiles in cooked ham: 2-methyl-3-furanthiol, 2-methyl-3-methyldithiofuran and bis(2-methyl-3-furyl) disulfide. The increase in thiamine addition was correlated with increasing contents of these three aroma compounds. Also the sensory analysis emphasizes the significance of thiamine as a precursor of cooked ham flavor (Thomas et al., 2015).

\section{Volatile compounds in various types of meat products}

The flavor of meat products is a resultant of multiple factors, the most important of which include: components and parameters of the production process. The key significance in finished product flavor development is ascribed to the type of applied meat as it affects the composition of volatile compounds. The key volatiles of cooked beef include: octanal, nonanal, (E,E)-2,4-decadienal, methanethiol, methional, 2-furfurylthiol, 2-metyl-3-furanthiol, 3-mercapto-2-pentanone, and 4-hydroxy-2,5-dimethyl-3-(2H)furanone. These compounds occur also in cooked pork and chicken meat, however their concentrations differ between species. The meaty-caramel odor notes typical of the cooked beef are attributable to high concentration of: 2-furfurylthiol, 2-methyl-3-furanthiol and 4-hydroxy-2,5-dimethyl-3-(2H)furanone. For comparison, a lower concentration of 4-hydroxy2,5-dimethyl-3-(2H)-furanone in pork results from significantly lower concentrations of its precursors, i.e. glucose 6-phosphate and fructose 6-phosphate. The concentration of carbonyl compounds with greasy odor notes, like hexanal, oxtanal and nonanal, is lower in pork than in beef. However, the ratios between contents of compounds imparting greasy notes and these imparting meaty notes are higher than in beef (Belitz et al., 2009). The most important volatile compounds of cooked poultry meat include: 2-furfurylthiol, hexanal, 2(E)-nonenal, 2,4(E,E)-nonadienal, 2,4(E,E)-decadienal and 2,4(E,Z)-decadienal (Kerler \& Grosch, 1997). During oxidation of poultry fat, (E,E)-2,4-decadienal and $\gamma$-dodecalacton are formed from linoleic acids that are typical of the chicken meat flavor (Gasser \& Grosch, 1991; Chen \& Ho, 1998). During long-term stewing of beef, 12-methyltridecanal appears which is an important compound from the viewpoint of retronasal olfaction as it is responsible for the characteristic sensation of satiety and flavor. This compound is typical of beef and is not formed upon heat treatment of pork and poultry meat.

A great part of research works are devoted to wet- and dry-cured meat products.

Wet-cured cooked hams were analyzed by, among others, (Ramarathnam et al., 1993; Leroy et al., 2009). Compared to the non-cured products, they are characterized by significantly lower contents of carbonyl compounds. They were also found to contain many volatile compounds originating from both reactions ongoing in meat as well as from added spices or the applied smoking process, i.e.: alkanes, alkenes, aldehydes, ketones, alcohols, aromatic hydrocarbons, carboxylic acids, esters, terpenes, sulfur compounds, furans, pyrazines, amines, and chloride. Nonetheless, only a small part of these compounds contribute to the development of a typical character of a product. They key volatiles identified included: terpenes (1,8 - cineole, linalool, L - carvone, cinnamaldehyde, menthol) originating from seasonings, as well as sulfur compounds and 3-methyl-butanoic acid formed upon Strecker degradation reaction (Toldrá \& Flores, 2007).

In the case of dry-cured hams, aldehydes, alcohols and ketones had a significant effect on the characteristic flavor of the finished products. Analyses showed the presence of: benzaldehyde, 2-heptanone, hexanal, hexanol, limonene, 3-methylbutanal, 2-nonanone, octanol, pentanol, propanone, and butanol (Luna et al., 2006; Garcia-Gonzalez et al., 2008).

An interesting group of meat products includes raw-ripened sausages. The volatile compounds formed during the ripening process belong to many classes. For example, 51 key volatiles were identified in a Hungarian-type Salami sausage. They included short-chain fatty acids and fermentation products (acetic acid, acetaldehyde, butanoic acid, and 3-methylbutanoic acid), as well as amino acid degradation products (methional, phenylacetaldehyde and 3-methylbutanal) (Söllner \& Schieberle, 2009).

\section{Conclusions}

Raw meat is weakly-flavored, however it constitutes a rich reservoir of compounds being precursors of volatile compounds. The flavor precursors of meat include mainly amino acids, reducing sugars, fats and thiamine, which during heat treatment impart the characteristic aroma of meat products. The formation of volatile compounds is a multi-directional process as a result of transformations linked with: Maillard reaction, lipid oxidation, interactions between Maillard reaction products and lipid oxidation products, and thiamine degradation. The final composition of volatile compounds in meat products is also determined by the additives applied and the course of technological processes.

\section{References}

Ames, J. M., Defaye, A. B., \& Bates, L. (1997). The effect of pH on the volatiles formed in an extruded starch-glucose-lysine model system. Food Chemistry, 58(4), 323-327. http://dx.doi.org/10.1016/ S0308-8146(96)00171-9.

Ames, J. M., Guy, R. C. E., \& Kipping, G. J. (2001). Effect of pH and temperature on the formation of volatile compounds in cysteine/ reducing sugar/starch mixtures during extrusion cooking. Journal of Agricultural and Food Chemistry, 49(4), 1885-1894. PMid:11308341. http://dx.doi.org/10.1021/jf0012547.

Ba, H. V., Hwang, I. H., Dawoon, J., \& Amna, T. (2012). Principle of meat aroma flavors and future prospect. In I. Akyar (Ed.), Latest research into quality control (chap. 7, pp. 145-176). Croatia: In Tech.

Balagiannis, D. P., Parker, J. K., Pyle, D. L., Desforges, N., Wedzicha, B. L., \& Mottram, D. S. (2009). Kinetic modeling of the generation of 2- and 3-methylbutanal in a heated extract of beef liver. Journal of Agricultural and Food Chemistry, 57(21), 9916-9922. PMid:19817419. http://dx.doi.org/10.1021/jf901443m.

Belitz, H. D., Grosch, W., \& Schieberle, P. (2009). Food chemistry. In H. D. Belitz, W. Grosch \& P. Schieberle. Meat (4th ed., Vol. 12, pp. 605-608). Berlin: Springer-Verlag.

Blank, I., Lin, J., Vera, F. A., Welti, D. H., \& Fay, L. B. (2001). Identification of potent odorants formed by autoxidation od arachidonic acid: structure elucidation and synthesis of $(\mathrm{E}, \mathrm{Z}, \mathrm{Z})$-2,4,7-tridecatrienal. 
Journal of Agricultural and Food Chemistry, 49(6), 2959-2965. PMid:11409993. http://dx.doi.org/10.1021/jf010160+.

Bruce, H. L., Beilken, S. L., \& Leppard, P. (2005). Textural, descriptions of cooked steaks from bovine M. longissimus thoracis et lumborum from different production and aging regimes. Journal of Food Science, 70(4), 309-316. http://dx.doi.org/10.1111/j.1365-2621.2005.tb07208.x.

Castellini, C., Berri, C., Le Bihan-Duval, E., \& Martino, G. (2008). Qualitative attributes and consumer perception of organic and freerange poultry meat. World's Poultry Science Journal, 64(4), 500-512. http://dx.doi.org/10.1017/S0043933908000172.

Cerny, C. (2012). Savory flavors. In: L. M. L. Nollet (Eds.), Handbook of meat, poultry and seafood quality (2nd ed.). Chichester: WileyBlackwell. http://dx.doi.org/10.1002/9781118352434.ch8.

Cerny, C., \& Davidek, T. (2003). Formation of aroma compounds from ribose and cysteine during the Maillard reaction. Journal of Agricultural and Food Chemistry, 51(9), 2714-2721. PMid:12696962. http://dx.doi.org/10.1021/jf026123f.

Chen, J., \& Ho, C. T.(1998). The flavour of pork. In F. Shahidi (Ed.), Flavor of meat, meat products and seafoods (pp. 62-83). London: Blackie Academic \& Professional.

Christlbauer, M., \& Schieberle, P. (2011). Evaluation of the key aroma compounds in beef and pork vegetable gravies a la chef by stable isotope dilution assays and aroma recombination experiments. Journal of Agricultural and Food Chemistry, 59(24), 13122-13130. PMid:22077665. http://dx.doi.org/10.1021/jf203340a.

Claeys, E., De Smet, S., Balcaen, A., Raes, K., \& Demeyer, D. (2004). Quantification of fresh meat peptides by SDS-PAGE in relation to aging time and taste intensity. Meat Science, 67(2), 281-288. PMid:22061325. http://dx.doi.org/10.1016/j.meatsci.2003.11.001.

Dashdorj, D., Amna, T., \& Hwang, I. (2015). Influence of specific tasteactive components on meat flavor as affected by intrinsic and extrinsic factors: an overview. European Food Research and Technology, 241(2), 157-171. http://dx.doi.org/10.1007/s00217-015-2449-3.

Domínguez, R., Gómez, M., Fonseca, S., \& Lorenzo, J. M. (2014). Influence of thermal treatment on formation of volatile compounds, cooking loss and lipid oxidation in foal meat. LWT - Food Science and Technology, 58(2), 439-445. http://dx.doi.org/10.1016/j.lwt.2014.04.006.

Elmore, J. S., Campo, M. M., Enser, M., \& Mottram, D. S. (2002). Effect of lipid composition on meat-like model systems containing cysteine, ribose and polyunsaturated fatty acids. Journal of Food Chemistry, 50(5), 1126-1132. PMid:11853493. http://dx.doi.org/10.1021/jf0108718.

Elmore, J. S., Warren, H. E., Mottram, D. S., Scollan, N. D., Enser, M., Richardson, I., \& Wood, J. D. (2004). Comparison of the aroma volatiles and fatty acid compositions of grilled beef muscle from Aberdeen Angus and Holstein Friesian steers fed diets based on silage or concentrates. Meat Science, 68(1), 27-33. PMid:22062004. http://dx.doi.org/10.1016/j.meatsci.2004.01.010.

Farmer, L. J., \& Mottram, D. S. (1992). Effect of cysteine and ribose on the volatile thermal degradation products of a triglyceride and three phospholipids. Journal of the Science of Food and Agriculture, 60(4), 489-497. http://dx.doi.org/10.1002/jsfa.2740600414.

Font-I-Furnols, M., \& Guerrero, L. (2014). Consumer preference, behavior and perception about meat and meat products: an overview. Meat Science, 98(3), 361-371. PMid:25017317. http://dx.doi.org/10.1016/j. meatsci.2014.06.025.

Garcia-Gonzalez, D. L., Tena, N., Aparicio-Ruiz, R., \& Morales, M. T. (2008). Relationship between sensory attributes and volatile compounds qualifying dry-cured hams. Meat Science, 80(2), 315-325. PMid:22063336. http://dx.doi.org/10.1016/j.meatsci.2007.12.015.
Gasser, U., \& Grosch, W. (1991). Aroma of cooked pork. Lebensmittelchemie, $45,15$.

Gerber, N., Scheeder, M. R. L., \& Wenk, C. (2009). The influence of cooking and fat trimming on the actual nutrient intake from meat. Meat Science, 81(1), 148-154. PMid:22063975. http://dx.doi. org/10.1016/j.meatsci.2008.07.012.

Gorraiz, C., Beriain, M. J., Chasco, J., \& Insausti, K. (2002). Effect of aging time on volatile compounds, odor, and flavor of cooked beef from Pirenaica and Friesian bulls and heifers. Journal of Food Science, 67(3), 916-922. http://dx.doi.org/10.1111/j.1365-2621.2002.tb09428.x.

Granvogl, M., Beksan, E., \& Schieberle, P. (2012). New insights into the formation of aroma-active Strecker aldehydes from 3-oxazolines as transient intermediates. Journal of Agricultural and Food Chemistry, 60(25), 6312-6322. PMid:22656242. http://dx.doi.org/10.1021/ jf301489j.

Grosch, W. (1993). Detection of potent odorants in foods by aroma extract dilution analysis. Trends in Food Science \& Technology, 4(3), 68-73. http://dx.doi.org/10.1016/0924-2244(93)90187-F.

Henriksen, A. P., \& Stahnke, L. H. (1997). Sensory and chromatographic evaluations of water soluble fractions from dried sausages. Journal of Agricultural and Food Chemistry, 45(7), 2679-2684. http://dx.doi. org/10.1021/jf960792+.

Hofmann, T., \& Schieberle, P. (1995). Evaluation of the key odorants in a termallytreated solution of ribose and cysteine by aroma extract dilution techniques. Journal of Agricultural and Food Chemistry, 43(8), 2187-2194. http://dx.doi.org/10.1021/jf00056a042.

Hofmann, T., Dunkel, A., Steinhaus, M., Kotthoff, M., Nowak, B., Krautwurst, D., \& Schieberle, P. (2014). Nature's chemical signatures in human olfaction: a foodborne perspective for future biotechnology. Angewandte Chemie International Edition, 53(28), 7124-7143. PMid:24939725. http://dx.doi.org/10.1002/anie.201309508.

Horsted, K., Allesen-Holm, B., Hermansen, J., \& Kongsted, A. (2012). Sensory profiles of breast meat from broilers reared in an organic niche production system and conventional standard broilers. Journal of the Science of Food and Agriculture, 92(2), 258-265. PMid:21800323. http://dx.doi.org/10.1002/jsfa.4569.

Huang, T. Ch., \& Ho, Ch. T. (2001). Meat science and applications. In Y. H. Hui, W. K. Nip, R.W. Rogers, O.A. Young (Eds.). Flavours of meat products (pp. 83-114). New York: Marcel Dekker.

Kerler, J., \& Grosch, W.(1997). Character impact odorants of boiled chicken: changes during refrigerated storage and reheating. Zeitschrift für Lebensmitteluntersuchung und -Forschung A, 205(3), 232-238.

Kostecka, M., \& Łobacz, M. (2009). Lipidy mięsa kurzego - tłuszcz nie(d) oceniony. Cz. I. Charakterystyka tłuszczu kurzego i wybrane metody modyfikacji. Postępy Techniki Przetwórstwa Spożywczego, 1, 98-103.

Leroy, F., Vasilopoulos, C., Vanhemelryck, S., Falony, G., \& Devuyst, L. (2009). Volatile analysis of spoiled, artisan - type, modified - atmosphere - packaged cooked ham stored under different temperatures. Food Microbiology, 26(1), 94-102. PMid:19028312. http://dx.doi.org/10.1016/j.fm.2008.08.005.

Liu, X. D., Jayasena, D. D., Jung, Y., Jung, S., Kang, B. S., Heo, K. N., Lee, J. H., \& Jo, C. (2012). Differential proteome analysis of breast and thigh muscles between Korean native chickens and commercial broilers. Asian-Australasian Journal of Animal Sciences, 25(6), 895902. PMid:25049642. http://dx.doi.org/10.5713/ajas.2011.11374.

Lorenzen, C. L., Davuluri, V. K., Adhikari, K., \& Grün, I. U. (2005). Effect of end point temperature and degree of doneness on sensory and instrumental flavor profile of beefsteaks. Journal of Food Science, 70(2), 113-118. http://dx.doi.org/10.1111/j.1365-2621.2005.tb07114.x. 
Luna, G., Aparicio, R., \& Garcia-Gonzalez, D. L. (2006). A tentative characterization of white dry-cured hams from Teruel (Spain) by SPME-GC. Food Chemistry, 97(4), 621-630. http://dx.doi.org/10.1016/j. foodchem.2005.05.039.

MacLeod, G. (1998). The flavor of beef. In F. Shahidi (Ed.), Flavor of meat and meat products and seafoods (2nd ed., pp. 5-81). London: Blackie Academic and Professional.

Majcher, M., \& Jeleń, H. H. (2007). Effect of cysteine and cystine addition on sensory profile and potent odorants of extruded potato snacks. Journal of Agricultural and Food Chemistry, 55(14), 5754-5760. PMid:17567142. http://dx.doi.org/10.1021/jf0703147.

Maślanko, W., \& Pisarski, R. K. (2009). The effect of herbs on the share of abdominal fat and its fatty acid profile in broiler chickens. Annales Universitatis Mariae Curie-Sklodowska, Sectio EE, 30(1), 28-34.

Meinert, L., Andersen, L. T., Bredie, W. L. P., Bjergegaard, Ch., \& Aaslyng, M. D. (2007). Chemical and sensory characterization of pan-fried pork flavor: Interaction between raw meat quality, ageing and frying temperature. Meat Science, 75(2), 229-242. PMid:22063654. http:// dx.doi.org/10.1016/j.meatsci.2006.07.004.

Meinert, L., Schäfer, A., Bjergegaard, C., Aaslyng, M. D., \& Bredie, W. L. P. (2009). Comparison of glucose, glucose 6-phosphate, ribose, and mannose as flavor precursors in pork; the effect of monosaccharide addition on flavor generation. Meat Science, 81(3), 419-425. PMid:22064277. http://dx.doi.org/10.1016/j.meatsci.2008.08.018.

Milczarek, A., Osek, M., Olkowski, B., \& Klocek, B. (2013). Porównanie składu chemicznego świeżych i zamrażalniczo przechowywanych mięśni kurcząt brojlerów żywionych mieszankami paszowymi z różną ilością oleju sojowego, lnianego i witaminy E. Żywność. Nauka. Technologia. Jakość, 1(86), 59-69.

Mottram, D. S. (1994). Meat flavor. In J. R. Piggott \& A. Paterson (Eds.), Understanding natural flavors (pp. 140-163). Glasgow: Chapman \& Hall.

Mottram, D. S. (1998). Flavor formation in meat and meat a review. Food Chemistry, 62(4), 415-424. http://dx.doi.org/10.1016/S03088146(98)00076-4.

Negroni, M., D’Agostina, A., \& Arnoldi, A. (2001). Effects of olive, canola, and sunflower oils on the formation of volatiles from the Maillard reaction of lysine with xylose and glucose. Journal of Agricultural and Food Chemistry, 49(1), 439-445. PMid:11170611. http://dx.doi. org/10.1021/jf0003653.

Ogasawara, M., Katsumata, T., \& Egi, M. (2006). Taste properties of Maillard reaction products prepared from 1000 to 5000 da peptide. Food Chemistry, 99(3), 600-604. http://dx.doi.org/10.1016/j. foodchem.2005.08.040.

Pan, S., Hu, Y., Chen, Q., Lei, S., Wu, P., Fan, G., \& Xu, X. (2011). Effects of lard on the formation of volatiles from the Maillard reaction of cysteine with xylose. Journal of the Science of Food and Agriculture, 91(12), 2241-2246. PMid:21618545.

Parker, J. K., Desforges, N., \& Mottram, D. S. (2009). Flavor development in a meat-based pet-food containing added glucose and glycine. Washington: American Chemical Society. AGFD-069.

Perez-Alvarez, J. A., Sendra-Nadal, E., Sanchez-Zapata, E. J., \& ViudaMartos, M. (2010). Poultry flavor: general aspects and applications.
In I. Guerrero-Legarreta \& Y. H. Hui (Eds.), Handbook of polutry sciences and technology: secondary processing (Vol. 2, pp. 339-357). New Jersey: John Wiley \& Sons.

Ramarathnam, N., Rubin, L. J., \& Diosady, L. L. (1993). Studies on meat flavor. 3. A novel method for trapping volatile components from uncured and cured pork. Journal of Agricultural and Food Chemistry, 41(6), 933-938. http://dx.doi.org/10.1021/jf00030a019.

Sato, M., Nakamura, T., Numata, M., Kuwahara, K., Homma, S., Sato, A., \& Fujimaki, M. (1995). Study on factors related to beef quality on the flavor and umami taste of Japanese Black cattle branded beef. Animal Science and Technology, 66, 274-282.

Shi, H., \& Ho, C. T. (1994). The flavour of poultry meat, In F. Shahidi (Ed.), Flavor of meat and meat products (pp. 52-69). Glasgow: Blackie Academic and Professional.

Sivadier, G., Ratel, J., \& Engel, E. (2010). Persistence of pasture feeding volatile biomarkers in lamb fats. Food Chemistry, 118(2), 418-425. http://dx.doi.org/10.1016/j.foodchem.2009.02.088.

Söllner, K., \& Schieberle, P. (2009). Decoding the key-aroma compounds of a Hungarian-type Salami by molecular sensory science approaches. Journal of Agricultural and Food Chemistry, 57(10), 4319-4327. PMid:19358532. http://dx.doi.org/10.1021/jf900402e.

Soncin, S., Chiesa, L. M., Cantoni, C., \& Biondi, P. A. (2007). Preliminary studyof the volatile fraction on the raw meat of pork, duck and goose. Journal of Food Composition and Analysis, 20(5), 436-439. http://dx.doi.org/10.1016/j.jfca.2006.09.001.

Stetzer, A. J., Cadwallader, K., Singh, T. K., Mckeith, F. K., \& Brewer, M. S. (2008). Effect of enhancement and ageing on flavor and volatile compounds in various beef muscles. Meat Science, 79(1), 13-19. PMid:22062593. http://dx.doi.org/10.1016/j.meatsci.2007.07.025.

Thomas, C., Mercier, F., Tournayre, P., Martin, J. L., \& Berdague, J. L. (2015). Effect of added thiamine on the key odorant compounds and aroma of cooked ham. Food Chemistry, 173, 790-795. PMid:25466091. http://dx.doi.org/10.1016/j.foodchem.2014.10.078.

Toldrá, F., \& Flores, M. (2007). Processed pork meat flavours. In Y. H. Hui, R. Chandan, S. Clark, N. Cross, J. Dobbs, W. J. Hurst, L. M. L. Nollet, E. Shimoni, N. Sinh, E. B. Smith, S. Surapat, A. Titchenal, F. Toldrá (Eds.), Handbook offood product manufacturing. New York: John Wiley Interscience.

Van Boekel, M. A. J. S. (2006). Formation of flavor compounds in the Maillard reaction. Biotechnology Advances, 24(2), 230-233. PMid:16386869. http://dx.doi.org/10.1016/j.biotechadv.2005.11.004.

Warris, P. D. (2000). Meat science (260 p.). Oxon: CABI Publishing.

Wojtasik-Kalinowska, I., Guzek, D., Górska-Horczyczak, E., Głąbska, D., Brodowska, M., Sun, D. V., \& Wierzbicka, A. (2016). Volatile compounds and fatty acids profile in Longissimus dorsi muscle from pigs fed with feed containing bioactive components. LWT - Food Science and Technology, 67, 112-117. http://dx.doi.org/10.1016/j. lwt.2015.11.023.

Wood, J., Enser, M., Fisher, A., Nute, G., Sheard, P., Richardson, R., Hughes, S. I., \& Whittington, F. M. (2008). Fat deposition, fatty acid composition and meat quality: a review. Meat Science, 78(4), 343-358. PMid:22062452. http://dx.doi.org/10.1016/j.meatsci.2007.07.019. 